\title{
Achieving Paris Climate Agreement Pledges: Alternative Designs for Linking Emissions Trading Systems
}

\author{
Adam Rose*, Dan Wei ${ }^{\dagger}$, Noah Miller, Toon Vandyck ${ }^{\S}$, and \\ Christian Flachsland"
}

\section{The 20 I 5 Paris Climate Agreement: Opening the Door to International Collaboration}

The Twenty-First Conference of the Parties (COP21) to the United Nations Framework Convention on Climate Change (UNFCCC), held in Paris in December 2015, resulted in 195 countries making voluntary greenhouse gas (GHG) reduction pledges, called Nationally Determined Contributions (NDCs). In a departure from their previous positions, many low- and middle-income (LMI) countries made substantial pledges to mitigate and sequester GHGs. However, the limited financial, technological, and institutional capacity of these countries raises challenges for the attainment of their COP21 pledges.

Several approaches have been proposed to overcome these barriers to climate policy in LMI countries. The first is direct financial or technology transfers, including use of the Green

${ }^{\star}$ Price School of Public Policy, University of Southern California (USC), Los Angeles, CA 90089; Tel: (213) 740-8022; Fax: (213) 821-3926; email: adam.rose@usc.edu.

${ }^{\dagger}$ Price School of Public Policy, University of Southern California (USC), 100D University Gateway, 3335 S Figueroa St, Los Angeles, CA 90007; Tel: (213) 740-0034; Fax: (213) 821-3926; email: danwei@usc.edu.

${ }^{\ddagger}$ Price School of Public Policy, University of Southern California (USC), University Gateway, 3335 S Figueroa St, Los Angeles, CA 90007; Tel: (510) 637-9799; email: nsmiller@usc.edu.

${ }^{\S}$ European Commission, Joint Research Centre, Edificio EXPO, Calle Inca Garcilaso 3, 41092 Seville, Spain; Tel: +34954 4882 67; email: vandycktoon@hotmail.com.

${ }$ Hertie School of Governance, Friedrichstraße 180, 10117 Berlin, Germany; and Mercator Research Institute on Global Commons and Climate Change (MCC), EUREF Campus 19, Torgauer Straße 12-15 10829 Berlin; Tel: +49 (0) 303385537 - 246; Fax: +49 (0) 303385537 - 102; email: flachsland@mcc-berlin.net.

This policy brief is an outgrowth of a paper presented at the May 29-30, 2017, Think 20 Global Solutions Summit, which provided policy briefs from "think tanks" to the G20 Summit. We are thankful to Dan Mazmanian, Lion Hirth, and Qi Ye for their helpful suggestions on the initial version. We also thank Frank Convery and an anonymous reviewer for helpful comments and Suzanne Leonard for extensive editing of the manuscript. The authors are solely responsible for the contents, which do not necessarily represent the views or recommendations of the institutions with which they are affiliated.

Review of Environmental Economics and Policy, volume 12, issue 1, Winter 2018, pp. 170-182 doi: $10.1093 /$ reep/rex029

(C) The Author(s) 2018. Published by Oxford University Press on behalf of the Association of Environmental and Resource Economists. All rights reserved. For Permissions, please email: journals.permissions@oup.com 
Climate Fund, ${ }^{1}$ which is aimed at providing much of the financing needed by LMI countries to meet the Paris pledges (UNFCCC 2015). However, payments into this fund are currently insufficient to reach the agreed-upon annual goal of $\$ 100$ billion. A second approach, included under Article 6 in the COP21 Paris Agreement, seeks to help countries meet their pledges by linking mitigation efforts internationally (Stavins and Stowe 2017). In particular, this might involve the linking of national and regional cap-and-trade (C\&T) systems that have been or are being implemented in several countries and regions. In this context, "linking" refers to the formal recognition of emission allowances issued under a C\&T system in one jurisdiction (a regional, national, or subnational government) by another jurisdiction for the purposes of complying with the first jurisdiction's requirements, and vice versa (Bodansky et al. 2016). Such linking will lead to the harmonization of initially asymmetric allowance prices across trading entities, which will lower the overall costs of achieving the same emissions reduction goals and can facilitate international financial transfers to LMI countries. Moreover, such linked carbon markets could form a common climate commitment that fosters broad international cooperation (Cramton, Ockenfels, and Tirole 2017).

Emissions trading is a policy instrument that has great promise for mitigating and sequestering GHGs. Successful applications include the European Union Emissions Trading System (EU ETS), the Regional Greenhouse Gas Initiative in the United States, the California Capand-Trade System, and the trading systems in Quebec (already linked with California in the context of the Western Climate Initiative) and Ontario (to be linked with California and Quebec beginning in 2018). Valuable experience has also been gained from the flexibility mechanisms under the Kyoto Protocol-that is, through the project-based Clean Development and Joint Implementation mechanisms and the government-level emissions trading provision that enables international transfer of so-called assigned amount units (AAUs). C\&T systems have the advantage of establishing a limit on the total amount of emissions while allowing purchases and sales between participants to attain this emissions cap at the lowest overall cost. Moreover, minimizing costs will enhance political support for achieving the ambitious global emissions reduction goals.

In theory, a system of international emissions allowance trading could be designed to achieve much of the COP2 1 GHG reduction pledges and subsequently the more ambitious goal of confining global average temperature increases from preindustrial levels to less than $2{ }^{\circ} \mathrm{C}$ or $1.5^{\circ} \mathrm{C}$ by the end of the century. Although economic theory predicts that a global, economy-wide emissions trading system covering all GHGs would provide the greatest cost savings, implementation may not be straightforward (Green, Sterner, and Wagner 2014).

This suggests that it may be more realistic to build up a global emissions trading system through a series of incremental programs that demonstrate the merits of such a system by first bringing on board the most willing countries. The G20 countries ${ }^{2}$ could demonstrate leadership in this regard by implementing regional or national C\&T systems and linking them among themselves; then, in a second stage, expanding the coverage nationally; and finally bringing in more countries over time. Thus the gains from emissions trading would be

\footnotetext{
${ }^{1}$ This fund was established at COP15 and reinforced at COP21.

${ }^{2}$ Table 1 lists G20 countries that made unconditional pledges in Paris (with the EU counting as a single entity). The remaining nonlisted countries are South Africa and Turkey. For brevity, throughout the article, references to the G20 countries indicate those listed in table 1.
} 
progressively increased in the process of international policy coordination. This policy brief examines the creation of an international emissions trading system that links national and regional C\&T systems (Flachsland, Marschinski, and Edenhofer 2009; Ranson and Stavins 2016; Rose et al. 2017a). ${ }^{3}$ More specifically, we consider a stepwise approach that focuses on two intermediate arrangements (stages) on a path to ultimately implementing a global system of GHG emissions trading:

- Stage 1-a G20 trading system that includes only subregions for some major countries (Canada, China, United States), ${ }^{4}$ while considering national coverage for the other G20 countries, in 2020 .

- Stage 2- a more complete arrangement composed of all regions of all G20 countries, in $2025 .^{5}$

- Stage 3- a full global system of all countries that offered unconditional pledges at COP 21 , in 2030 .

These stages would coincide with the five-year pledge-and-review cycles of the UNFCCC and allow for quantitative comparisons of progress across countries (Aldy et al. 2017).

Many countries have regulations in place for GHG mitigation options that are less responsive to a price signal (e.g., renewable portfolio standards [RPSs] for electricity generation, land use planning, vehicle standards, energy efficiency labels). Although linking mitigation efforts across countries could, in principle, include heterogeneous policies (Metcalf and Weisbach 2012; Bodansky et al. 2016), harmonizing nonprice measures are likely to face institutional challenges. Thus our analysis focuses only on linking C\&T systems. We also distinguish between emissions reductions from C\&T and those due to other policy instruments. The remainder of our discussion is as follows. In the next section we provide an overview of the methodology. This is followed by an analysis of the simulation results for each of the three stages. We then discuss the equity implications of each stage of the trading system. We conclude with a summary and policy recommendations.

\section{A Quantitative Exploration of Future International Cooperation: Overview of Analytical Approach}

For our analysis we use information on unconditional Paris pledges, emissions projections, and mitigation costs, combined with well-established economic modeling, to generate

\footnotetext{
${ }^{3}$ Not all countries are amenable to an allowance trading system. However, the effect of implementing a harmonized carbon tax (a strong alternative to allowance trading) across countries would have a very similar outcome to linking pure auction-based trading systems in terms of allocating mitigation efforts (Cramton, Ockenfels, and Tirole 2017). In the tax case, however, individual countries would collect the tax and could transfer some of the revenues (in a manner similar to transferring allowance auction revenues) to LMI countries.

${ }^{4}$ We base these subregions on areas that have already implemented C\&T systems, such as the Regional Greenhouse Gas Initiative (RGGI) and Western Climate Initiative (WCI) in the United States, which could more easily work towards international system linkages, as, for example, California and Quebec have already done.

${ }^{5}$ Note that we include the entire EU (and all of its member countries) as a single entity, which maintains its own emissions trading system (i.e., the EU ETS) and which would link in its entirety with other systems.
} 
simulations of the costs and savings from implementing the three stages of the proposed C\&T system, as well as the costs of non-C\&T GHG reductions.

The management of an international C\&T system requires a careful institutional design. In particular, linked carbon markets result in interdependencies between participating countries' policies, with unilateral institutional changes (e.g., adjustment of caps or related policies such as RPSs) affecting all other participants in the trading system (Burtraw et al. 2013). ${ }^{6}$ Moreover, when designing an international system that combines C\&T programs across borders, it is important to consider a number of features. The ones we examine include: (1) regional coverage, (2) sectoral coverage, (3) GHG coverage, (4) grandfathering or auctioning allowances, (5) allocation of auction revenues, (6) supplementary transfers, and (7) stringency and evolution of the cap.

The numerical analysis that forms the basis of this policy brief combines the unconditional NDCs of ninety countries - aggregated into fifteen regions - with data from the Climate Equity Reference Project (CERP 2016) and the World Resources Institute (WRI 2016). We derive macroeconomic marginal mitigation cost curves from the global General Equilibrium Model for Economy - Energy - Environment (GEM-E3), an integrated energy, environment, and economic model (Vandyck et al. 2016). The cost curves are then inserted into a mitigation cost-minimizing model developed for emissions trading analysis (Rose et al. 1998) and recently refined for the Paris Agreement (Rose et al. 2017b). Then, based on a meta-analysis of the database underlying the Intergovernmental Panel on Climate Change's Fifth Assessment Report (AR5), we derive an estimate of the shift of the marginal mitigation costs that result from technological progress over time. ${ }^{7}$

The simulations we present here consider C\&T systems based on carbon dioxide $\left(\mathrm{CO}_{2}\right)$ emissions in the power and industry sectors alone, as this is the common denominator across existing trading schemes. Emission reductions in other sectors, such as households and transportation, are assumed to be achieved through non-C\&T policies (mainly regulations). We derive separate cost curves for non-C\&T sectors and for $\mathrm{CO}_{2}$ in $\mathrm{C} \& \mathrm{~T}$ sectors. ${ }^{8}$

The simulations explore a gradual stepwise expansion of the regional coverage of allowance markets for $\mathrm{CO}_{2}$ emissions in the power and industry sectors, starting with national and subnational (for Canada, China, and the United States) coverage in 2020 (stage 1), then linking all G20 countries' allowance markets in 2025 (stage 2), and finally considering global coverage in 2030 (stage 3$)^{9}$

\footnotetext{
${ }^{6}$ Note that we do not address some potential complications of linking C\&T systems. For details, see, e.g., Doda and Taschini (2017).

${ }^{7} \mathrm{We}$ do this by adjusting the slope parameters of the C\&T sector cost curves downward from 2020 to 2025 and then further downward to 2030 (see appendix C in the online supplementary materials).

${ }^{8}$ We use the GEM-E3 model to derive the marginal abatement cost curves in both C\&T and non-C\&T sectors. How the mitigation effort is shared between C\&T and non-C\&T sectors is based on the results of the Prospective Outlook on Long-term Energy Systems (POLES) model (Kitous et al. 2016).

${ }^{9}$ Although carbon leakage-i.e., the increase of emissions in some jurisdictions in response to other jurisdictions' unilateral emission reduction efforts-is a relevant concern in the strategic analysis of international climate policy (Nordhaus 2015), the analysis here assumes that countries that are not included in the intermediate stages of our global emission trading system (i.e., stages 1 and 2) will still meet their Paris pledges.
} 


\section{Stage I: Linking G20 National and Subnational C\&T Systems in $\mathbf{2 0 2 0}$}

The results for stage 1 indicate that linking national and subnational C\&T systems of G20 countries offers significant benefits. More specifically, we find that emissions trading that covers the power and industry sectors can reduce the total associated mitigation costs of G20 participating countries (or subcountry regions) from $\$ 73$ billion (in 2015 dollars) to $\$ 30$ billion, or a savings of more than 59 percent (see table 1). Generally, regions with high marginal costs of mitigation in the power and industry sectors are allowance buyers and regions with low marginal costs are allowance sellers. For example, the United States, EU, and other high-income regions are buyers, while countries like China, India, and Russia are sellers. However, the results also indicate that each country gains from participating in the emissions trading, whether it is an allowance purchaser or seller (see "Cost savings" column in table 1). In addition, some countries (such as Argentina) with no mitigation obligations (over and above their mitigation associated with compliance to in-country regulations) can still benefit from joining a trading system by selling emission allowances. Finally, given the strong push many high-income countries have already been making towards emissions reductions in the power and industry sectors, many of them would meet 100 percent of their interpolated intermediate 2020 pledges submitted to COP2 1 without additional reductions in the non-C\&T sector. Thus these costs associated with the non-C\&T sector mitigations are relatively low or even zero.

\section{Stage 2: Linking C\&T Systems of G20 Countries in 2025}

The results for stage 2 (see appendix table 1) indicate that linking the C\&T systems of G20 members in 2025 can bring them sizeable benefits. This stage simulates GHG emissions trading in 2025 among the G20 members that made unconditional pledges at COP21, assuming full national coverage within countries. Again, the shape of the marginal cost curve is a major determinant of a country's buyer or seller status. However, unlike under stage 1, many LMI regions become allowance buyers, including more advanced countries (e.g., Brazil) and countries with relatively much lower per capita income (e.g., Indonesia). One reason for this result is that these countries have made high pledges, both in absolute terms and in relative terms compared to their mitigation commitments prior to COP21 (Rose et al. 2017b). This result is also driven by the vast potential for inexpensive GHG mitigation in China and India. The results indicate that while China and India, as major allowance sellers, more than offset their mitigation costs (i.e., resulting in a negative net cost), LMI countries such as Mexico and Indonesia will incur more than $\$ 10$ billion in annual net costs. Note, however, that this value would be more than $\$ 17$ billion without emissions trading. In addition, all regions are better off with trading, but the lower-income regions' net cost savings is smaller in both absolute and relative terms.

Stage 2 has advantages over stage 1: (1) the total emissions reduction in the C\&T sectors is 196 percent higher and (2) although mitigation costs nearly double, the percentage cost savings from trading increase from 59 percent to 75 percent. The major reasons for these differences between the two stages are the increased GHG reduction goals over time and the 
Table I Simulation of emissions allowance trading in stage I: G20 national and subnational systems in 2020 (in million 2015\$ unless otherwise indicated)

\begin{tabular}{|c|c|c|c|c|c|c|c|c|}
\hline \multirow{2}{*}{$\begin{array}{l}\text { Trading } \\
\text { party }\end{array}$} & \multirow{2}{*}{$\begin{array}{c}\begin{array}{c}\text { Before } \\
\text { trading }\end{array} \\
\begin{array}{c}\text { C\&T } \\
\text { mitigation } \\
\text { cost }\end{array}\end{array}$} & \multicolumn{6}{|c|}{ After trading } & \multirow{2}{*}{$\begin{array}{l}\text { Non-C\&T } \\
\text { mitigation } \\
\text { cost }\end{array}$} \\
\hline & & $\begin{array}{c}\text { Allowances } \\
\text { traded } \\
\left(\mathrm{mtCO}_{2}\right)\end{array}$ & $\begin{array}{c}\text { Emissions } \\
\text { reduction } \\
\left(\mathrm{mtCO}_{2}\right)\end{array}$ & $\begin{array}{c}\text { C\&T } \\
\text { mitigation } \\
\text { cost }\end{array}$ & $\begin{array}{l}\text { Trading } \\
\cos ^{\mathrm{a}, \mathrm{b}}\end{array}$ & $\begin{array}{l}\text { Net } \\
\text { cost }\end{array}$ & $\begin{array}{c}\text { Cost } \\
\text { savings }\end{array}$ & \\
\hline Argentina & 0 & -9 & 9 & 526 & -642 & -116 & 116 & 514 \\
\hline Australia & 434 & 3 & 0 & 0 & 182 & 182 & 251 & 1,172 \\
\hline Brazil & 10,795 & 88 & 0 & 0 & 5,994 & 5,994 & 4,801 & 778 \\
\hline Canada & 279 & 3 & 0 & 0 & 213 & 213 & 66 & 0 \\
\hline China & 102 & -99 & 101 & 5,817 & $-6,732$ & -916 & 1,018 & 0 \\
\hline EU & 31,770 & 299 & 0 & 0 & 20,373 & 20,373 & 11,397 & 0 \\
\hline India & 0 & -349 & 349 & 18,274 & $-23,784$ & $-5,510$ & 5,510 & 0 \\
\hline Indonesia & 0 & 0 & 0 & 0 & 0 & 0 & 0 & 2,898 \\
\hline Japan & 2,292 & -7 & 48 & 2,788 & -510 & 2,279 & 13 & 0 \\
\hline South Korea & 20,242 & 94 & 0 & 0 & 6,407 & 6,407 & 13,835 & 0 \\
\hline Mexico & 51 & -18 & 19 & 1,082 & $-1,245$ & -162 & 213 & 635 \\
\hline Russia & 0 & -25 & 25 & 1,656 & $-1,728$ & -73 & 73 & 0 \\
\hline Saudi Arabia & 297 & 2 & 0 & 0 & 117 & 117 & 180 & 326 \\
\hline USA & 6,467 & 20 & 0 & 0 & 1,354 & 1,354 & 5,113 & 353 \\
\hline Total & 72,729 & 508 & 552 & 30,142 & 0 & 30,142 & 42,586 & 6,676 \\
\hline
\end{tabular}

Notes: Analysis assumes free allocation of allowances and includes only power and industry sectors covered by C\&T. Analysis also assumes the trading system includes only the national/partial G20 countries/regions with unconditional pledges and hence excludes South Africa and Turkey.

${ }^{a}$ Allowance price: $\$ 68.24 / \mathrm{tCO}_{2} \mathrm{e}$; average mitigation cost with trading: $\$ 54.63 / \mathrm{tCO}_{2} \mathrm{e}$. ${ }^{\mathrm{b}} \mathrm{Negative}$ entries signify revenues from allowance sales.

Source: The authors.

89 percent additional emissions reduction potential of expanding China's regional coverage to the entire country.

\section{Stage 3: A Global Carbon Market in 2030}

The results for stage 3-which simulates GHG emissions trading in the power and industry sectors in 2030 for all ninety countries (fifteen aggregated regions) that made unconditional pledges at COP21 - indicate that there is great potential for broader emissions trading to substantially reduce mitigation costs. More specifically, in this stage, emissions trading could reduce total mitigation costs from $\$ 900$ billion to $\$ 252$ billion, a savings of 72.1 percent, while still achieving the pledged emissions reductions (see table 2). This cost saving is consistent with other estimates of the benefits of allowance trading under the Kyoto Protocol and Paris COP21 Agreement, which range from approximately 60 percent (Böhringer 2000), to 75 percent (Fujimori et al. 2016), to 88 percent (Nordhaus and Boyer 1999). More than 3.4 billion tons of $\mathrm{CO}_{2}$ equivalent $\left(\mathrm{tCO}_{2} \mathrm{e}\right)$ in emissions allowances would be traded at a price of $\$ 83.78$ per $\mathrm{tCO}_{2} \mathrm{e}$ and an average cost per $\mathrm{tCO}_{2} \mathrm{e}$ reduction of $\$ 63.75$ in 2030. This allowance price is higher than the price under stages 1 and 2, primarily because a much higher emissions 
Table 2 Simulation for stage 3: emissions trading among ninety countries in 2030 (in million $2015 \$$ unless otherwise indicated)

\begin{tabular}{|c|c|c|c|c|c|c|c|c|}
\hline \multirow{2}{*}{$\begin{array}{l}\text { Trading } \\
\text { party }\end{array}$} & \multirow{2}{*}{$\begin{array}{c}\begin{array}{c}\text { Before } \\
\text { trading }\end{array} \\
\begin{array}{c}\text { C\&T } \\
\text { mitigation } \\
\text { cost }\end{array}\end{array}$} & \multicolumn{6}{|c|}{ After trading } & \multirow{2}{*}{$\begin{array}{c}\text { Non-C\&T } \\
\text { mitigation } \\
\text { cost }\end{array}$} \\
\hline & & $\begin{array}{c}\text { Allowances } \\
\text { traded } \\
\left(\mathrm{mtCO}_{2}\right)\end{array}$ & $\begin{array}{l}\text { Emissions } \\
\text { reduction } \\
\left(\mathrm{mtCO}_{2}\right)\end{array}$ & $\begin{array}{c}\text { C\&T } \\
\text { mitigation } \\
\text { cost }\end{array}$ & $\begin{array}{l}\text { Trading } \\
\text { cost }^{\mathrm{a}, \mathrm{b}}\end{array}$ & $\begin{array}{l}\text { Net } \\
\text { cost }\end{array}$ & $\begin{array}{l}\text { Cost } \\
\text { savings }\end{array}$ & \\
\hline Australia & 2,072 & 12 & 0 & 0 & 1,032 & 1,032 & 1,040 & 80,608 \\
\hline Brazil & 19,912 & 139 & 11 & 916 & 11,666 & 12,582 & 7,330 & 196,158 \\
\hline Canada & 16,437 & 137 & 0 & 0 & 11,519 & 11,519 & 4,918 & 104,352 \\
\hline China & 12,007 & $-2,401$ & 2,643 & 170,355 & $-201,159$ & $-30,804$ & 42,811 & 589 \\
\hline EU 28 & 116,856 & 725 & 74 & 5,839 & 60,728 & 66,568 & 50,288 & 190,138 \\
\hline India & 0 & -849 & 849 & 49,877 & $-71,136$ & $-21,259$ & 21,259 & 0 \\
\hline Japan & 5,890 & 0 & 92 & 5,901 & -11 & 5,890 & 0 & 51,041 \\
\hline $\begin{array}{l}\text { Mexico and } \\
\text { South America }\end{array}$ & 32,625 & 185 & 145 & 9,072 & 15,495 & 24,567 & 8,057 & 6,249 \\
\hline $\begin{array}{l}\text { North Africa } \\
\text { and Middle East }\end{array}$ & 11,596 & 64 & 0 & 0 & 5,383 & 5,383 & 6,213 & 19,444 \\
\hline Rest of Europe & 1,893 & 12 & 0 & 0 & 983 & 983 & 910 & 9,673 \\
\hline Rest of the world & 97,288 & 716 & 0 & 0 & 59,948 & 59,948 & 37,340 & 126,295 \\
\hline Russia & 0 & -132 & 132 & 9,617 & $-11,089$ & $-1,472$ & I,472 & 0 \\
\hline $\begin{array}{l}\text { Singapore and } \\
\text { South Korea }\end{array}$ & 80,227 & 250 & 0 & 0 & 20,942 & 20,942 & 59,286 & 10,404 \\
\hline $\begin{array}{l}\text { Ukraine, Belarus, } \\
\text { and Moldova }\end{array}$ & 0 & 0 & 0 & 0 & 0 & 0 & 0 & 0 \\
\hline United States & 503,992 & 1,142 & 0 & 0 & 95,699 & 95,699 & 408,294 & 228,362 \\
\hline Total & 900,795 & 3,383 & 3,946 & 251,578 & 0 & 251,578 & 649,217 & $1,023,313$ \\
\hline
\end{tabular}

Notes: Simulation aggregates the ninety countries into fifteen regions. Analysis assumes free allocation of allowances and includes only power and industry sectors covered by C\&T.

${ }^{a}$ Allowance price: $\$ 83.78 / \mathrm{tCO}_{2} \mathrm{e}$; average mitigation cost with trading: $\$ 63.75 / \mathrm{tCO}_{2}$ e. ${ }^{\mathrm{b}} \mathrm{Negative}$ entries signify revenues from allowance sales.

Source: The authors.

reduction goal needs to be achieved in 2030 in order to meet 100 percent of the unconditional pledges.

As with the other simulations, the results for stage 3 indicate that although all regions are better off with emissions trading, the net cost savings for the lowest-income regions are smaller in both absolute and relative terms. In effect, although emissions trading results in sizable cost savings for high-income regions, the cost savings are minimal for LMI regions, suggesting an inequity in the distribution of benefits (Kverndokk and Rose 2008). ${ }^{10}$ Note that by 2030 (see table 2), much greater reductions are undertaken in the non-C\&T sectors, which increase the associated costs considerably. This provides further support for the $\$ 100$ billion annual fund to help low-income countries meet their pledges, which was endorsed by the Paris Agreement.

\footnotetext{
${ }^{10}$ This conclusion is based on the analysis of the distribution of mitigation burden in terms of traditional equity principles such as ability to pay and egalitarian equity (see Rose et al. 2017b).
} 


\section{Using International Transfer of Auction Revenue to Address Equity Issues}

With these equity concerns in mind, we next consider a system design that would generate at least $\$ 100$ billion in auction revenue that could be transferred to LMI countries (see appendix table 2). Under this design, the five highest-income regions purchase 13 percent of their allowances at auction (or internally auction at least this share of allowances and transfer the resulting funds internationally) and the remaining regions receive all of their allowances freely. Consistent with economic theory, this system results in the same allowance price (both in the trading market and auction) as in the pure trading system and results in the same cost savings for all LMI regions as under stage 3. However, the five highest-income regions become worse off than in the 100 percent grandfathering case because of their need to pay for the additional 13 percent of allowance value. The lowest-income regions ("Rest of the world" in appendix table 2) would still incur $\$ 60$ billion in total net costs in the C\&T sectors and $\$ 126.3$ billion in non-C\&T costs, as shown for stage 3 in table 2 . Thus, although equal to the climate financing fund target, the $\$ 101.8$ billion of auction revenue would only partially offset the cost burden on the poorest countries.

\section{Contributions of China and the United States}

Next, we examined the contributions of China and the United States, the world's two largest economies and GHG emitters, to the global trading system by simulating their nonparticipation in the system. ${ }^{11}$ The results indicate that China's absence would have the larger impact on cost within the system, with the allowance price nearly doubling and the total emissions reduction within the trading coalition declining from 15.3 percent to 14.6 percent. If the United States does not participate, the allowance price falls because of a large drop in demand, and the percentage of GHG emissions reduction within the trading coalition would fall significantly, to 11.9 percent. Another implication of the United States nonparticipation is that the total mitigation cost for the rest of the world (i.e., mostly LMI countries in Africa, Southeast Asia, and Central and South America that made unconditional pledges at COP21) would decline by $\$ 8.6$ billion. This is because the United States is a major allowance buyer, and the allowance price decreases when it does not participate. ${ }^{12}$ Additionally, Japan would become an allowance buyer. Overall, the nonparticipation of either China or the United States would reduce the total cost savings and the emissions reduction that could be achieved through the trading coalition.

\section{Conclusion and Policy Recommendations}

The coordination of international climate policy, such as linking systems of tradable GHG emissions allowances, can greatly lower the cost to all participants of slowing climate change. Using a stepwise approach, we have examined three incremental policy stages to implement the 2015 Paris Climate Agreement's GHG reduction pledges. More specifically, we have

\footnotetext{
${ }^{11}$ See table $\mathrm{S} 4$ in the online supplementary materials for detailed results.

${ }^{12}$ Note that the total C\&T cost when the United States does not participate is lower than in the base case. This is because the total GHG emissions reduction within the trading coalition is lower than in the base case.
} 
estimated the costs and benefits of alternative configurations of participating countries and examined the importance of allowance trading design features, such as the transfer of auction revenues to low-income countries. Across the three stages, we find that adopting a C\&T system makes all G20 countries better off and that the non-G20 countries included in the analysis are also better off in the case of global (ninety-country) emissions trading (see table 2). Moreover, the results indicate that under a partial auction, the $\$ 100$ billion climate financing fund target could be easily fulfilled without severely impacting the savings to countries participating in the proposed global emissions trading system.

To summarize (see table 3), stage 1 indicates that simply by linking the existing G20 national and subnational C\&T systems, more than 23 percent of world emissions would be covered, reducing these emissions in the C\&T sectors by 1.02 percent, ${ }^{13}$ while saving more than $\$ 42.5$ billion (59 percent) in mitigation costs. Stage 2 , which expands the system to fully include all G20 countries, increases the coverage of world emissions to almost 46 percent and their reduction to 2.75 percent in C\&T sectors, while increasing the mitigation cost savings to more than $\$ 268$ billion (75 percent). Finally, stage 3, which expands the system to cover all countries that submitted unconditional NDCs, covers almost 50 percent of world emissions, results in a 6 percent emissions reduction in C\&T sectors, and further increases global mitigation cost savings to nearly $\$ 650$ billion (72 percent).

The results of our analysis support several policy recommendations:

1. G20 countries should display leadership in establishing and linking C\&T systems to realize significant economic benefits in the implementation of the Paris Climate Agreement. Progress by G20 countries in linking C\&T systems has the potential to illuminate the path forward towards a truly global system of emissions trading that would further reduce total costs for all countries achieving their pledged emission reductions.

2. Use emissions trading systems to mobilize financial support of $\$ 100$ billion annually for low-income countries to support them in meeting their COP21 pledges. Our findings indicate that auctioning 13 percent of the allowances in the five highest-income regions would generate sufficient auction revenue to mobilize the $\$ 100$ billion annual transfer endorsed by the Paris Agreement.

3. If full linking of C\&T systems is not feasible, international harmonization of domestic carbon prices should be pursued. Linking C\&T systems involves a number of practical challenges, including the need for-and the increased complexity of-governing a joint system. This might lead to conflicts if the climate policy preferences of linking regions (such as preferred levels of carbon prices) are very diverse. A more modest alternative would be to internationally harmonize domestic carbon prices (e.g., via coordinated GHG taxes or price floors in C\&T systems). This would reap most or all of the efficiency gains of fully linked allowance trading. Such international policy coordination may need to be complemented by international cash transfers in order to

\footnotetext{
${ }^{13}$ This is primarily because countries are expected to achieve only a small amount of their pledged emissions reduction in 2020: 17 percent for countries that include land use, land use change, and forestry (LULUCF) in their NDC and 30 percent for countries that exclude LULUCF. Moreover, only about one-third of the pledged emissions reduction is achieved by the C\&T sector.
} 
Table 3 Summary of mitigation costs and expected savings under incremental emissions trading stages

\begin{tabular}{|c|c|c|c|c|c|c|}
\hline \multirow[t]{2}{*}{ Country } & \multicolumn{2}{|c|}{ Partial G20 stage (2020) } & \multicolumn{2}{|c|}{ Full G20 stage (2025) } & \multicolumn{2}{|c|}{ Global stage $^{d}(2030)$} \\
\hline & $\begin{array}{c}\text { Allowance } \\
\text { purchases/ } \\
\text { sales }\end{array}$ & $\begin{array}{c}\text { Cost } \\
\text { savings }(\%)^{b}\end{array}$ & $\begin{array}{c}\text { Allowance } \\
\text { purchases/ } \\
\text { sales }\end{array}$ & $\begin{array}{c}\text { Cost } \\
\text { savings (\%) }\end{array}$ & $\begin{array}{c}\text { Allowance } \\
\text { purchases/ } \\
\text { sales }\end{array}$ & $\begin{array}{c}\text { Cost } \\
\text { savings (\%) }\end{array}$ \\
\hline Argentina $[\mathrm{MSA}]^{\mathrm{a}}$ & -9 & $-^{c}$ & 14 & 15.13 & {$[185]$} & {$[24.70]$} \\
\hline Australia & 3 & 57.83 & 3 & 59.29 & 12 & 50.19 \\
\hline Brazil & 88 & 44.47 & 47 & 30.17 & 139 & 36.81 \\
\hline Canada & 3 & 23.66 & 52 & 35.14 & 137 & 29.92 \\
\hline China & -99 & 998.04 & -990 & 156.10 & $-2,401$ & 356.55 \\
\hline EU & 299 & 35.87 & 503 & 46.83 & 725 & 43.03 \\
\hline India & -349 & - & -431 & - & -849 & - \\
\hline Indonesia [ROW] & 0 & - & 143 & 43.95 & {$[12]$} & [38.38] \\
\hline Japan & -7 & 0.57 & -52 & - & 0 & - \\
\hline South Korea [SSK] & 94 & 68.35 & 146 & 72.31 & {$[250]$} & {$[73.90]$} \\
\hline Mexico [MSA] & -18 & 417.65 & -9 & 5.93 & {$[185]$} & [24.70] \\
\hline Russia & -25 & - & -19 & - & -132 & - \\
\hline Saudi Arabia [NAM] & 2 & 60.61 & 0 & - & [64] & [53.58] \\
\hline USA & 20 & 79.06 & 593 & 82.73 & $\mathrm{I}, 142$ & 81.01 \\
\hline G20 total [Global total] & 508 & 58.55 & $\mathrm{I}, 502$ & 74.77 & {$[3,383]$} & [72.07] \\
\hline Allowance price & \multicolumn{2}{|c|}{$\$ 68.24 / \mathrm{tCO}_{2} \mathrm{e}$} & \multicolumn{2}{|c|}{$\$ 65.99 / \mathrm{tCO}_{2} \mathrm{e}$} & \multicolumn{2}{|c|}{$\$ 83.78 / \mathrm{tCO}_{2} \mathrm{e}$} \\
\hline $\begin{array}{l}\text { Global emissions } \\
\text { covered by } \\
\text { C\&T system (\%) }\end{array}$ & \multicolumn{2}{|c|}{23.44} & \multicolumn{2}{|c|}{45.55} & \multicolumn{2}{|c|}{49.90} \\
\hline $\begin{array}{l}\text { Global emissions } \\
\text { reduced by } \\
\text { C\&T system (\%) }\end{array}$ & \multicolumn{2}{|c|}{1.02} & \multicolumn{2}{|c|}{2.75} & \multicolumn{2}{|c|}{6.01} \\
\hline $\begin{array}{c}\text { Total emissions } \\
\text { reduced (\%) } \\
\text { G20 [global] }\end{array}$ & \multicolumn{2}{|c|}{3.13} & \multicolumn{2}{|c|}{8.76} & \multicolumn{2}{|c|}{ [13.98] } \\
\hline
\end{tabular}

${ }^{a}$ Brackets denote which of the respective fifteen regions a G20 country belongs to and that region's values in the global stage. MSA $=$ Mexico and South America; ROW = rest of the world; SSK = Singapore and South Korea; NAM = North Africa and Middle East. ${ }^{b}$ As a percentage of C\&T sector mitigation costs. ${ }^{C}$ Undefined due to zero-cost before trading. Including only those countries that offered unconditional NDCs at COP2I. ${ }^{\mathrm{e} C o m p a r e d}$ with a business-as-usual baseline without the Paris Agreement pledges.

compensate for increased policy stringency in countries that have lower carbon prices initially.

4. The design and implementation of an integrated international allowance trading system should be considered within a broader policy context that includes accompanying measures. In particular, a monitoring, reporting, and verification framework is needed to guarantee the additionality of emissions reductions under the trading system. Governance arrangements are also necessary to coordinate reforms in individual linked systems that can affect the functioning of the integrated market. Finally, capacity building to improve institutional frameworks in LMI countries, as well as technology transfers, may be required to help these countries fulfill their COP21 pledges. 


\section{Appendix. Additional Simulation Results of Emissions Allowance Trading Stages}

Appendix Table I Simulation of emissions allowance trading in stage 2: national coverage of G20 countries in 2025 (in million 2015\$ unless otherwise indicated)

\begin{tabular}{|c|c|c|c|c|c|c|c|c|}
\hline \multirow{2}{*}{$\begin{array}{l}\text { Trading } \\
\text { party }\end{array}$} & \multirow{2}{*}{$\begin{array}{c}\begin{array}{c}\text { Before } \\
\text { trading }\end{array} \\
\begin{array}{c}\text { C\&T } \\
\text { mitigation } \\
\text { cost }\end{array}\end{array}$} & \multicolumn{6}{|c|}{ After trading } & \multirow{2}{*}{$\begin{array}{l}\text { Non-C\&T } \\
\text { mitigation } \\
\text { cost }\end{array}$} \\
\hline & & $\begin{array}{c}\text { Allowances } \\
\text { traded } \\
\left(\mathrm{mtCO}_{2}\right)\end{array}$ & $\begin{array}{c}\text { Emissions } \\
\text { reduction } \\
\left(\mathrm{mtCO}_{2}\right)\end{array}$ & $\begin{array}{c}\text { C\&T } \\
\text { mitigation } \\
\text { cost }\end{array}$ & $\begin{array}{l}\text { Trading } \\
\text { cost }^{\mathbf{a}, \mathrm{b}}\end{array}$ & $\begin{array}{l}\text { Net } \\
\text { cost }\end{array}$ & $\begin{array}{c}\text { Cost } \\
\text { savings }\end{array}$ & \\
\hline Argentina & $|, 77|$ & 14 & 11 & 586 & 917 & 1,503 & 268 & 484 \\
\hline Australia & 560 & 3 & 0 & 0 & 228 & 228 & 332 & 29,995 \\
\hline Brazil & 4,425 & 47 & 0 & 0 & 3,089 & 3,089 & 1,335 & 57,678 \\
\hline Canada & 5,308 & 52 & 0 & 0 & 3,442 & 3,442 & $\mathrm{I}, 865$ & 50,034 \\
\hline China & 5,353 & -990 & 1,099 & 62,341 & $-65,345$ & $-3,004$ & 8,356 & 243 \\
\hline EU & 62,422 & 503 & 0 & 0 & 33,187 & 33,187 & 29,235 & 20,488 \\
\hline India & 0 & -431 & 431 & 22,204 & $-28,463$ & $-6,259$ & 6,259 & 0 \\
\hline Indonesia & 16,805 & 143 & 0 & 0 & 9,420 & 9,420 & 7,385 & 0 \\
\hline Japan & 0 & -52 & 52 & 2,952 & $-3,442$ & -489 & 489 & 0 \\
\hline South Korea & 34,898 & 146 & 0 & 0 & 9,665 & 9,665 & 25,233 & 0 \\
\hline Mexico & 691 & -9 & 22 & 1,226 & -576 & 651 & 41 & 6,159 \\
\hline Russia & 0 & -19 & 19 & 1,233 & $-1,266$ & -33 & 33 & 0 \\
\hline Saudi Arabia & 0 & 0 & 0 & 0 & 0 & 0 & 0 & 5,328 \\
\hline USA & 226,609 & 593 & 0 & 0 & 39,143 & 39,143 & 187,466 & 47,010 \\
\hline Total & 358,840 & 1,502 & 1,635 & 90,543 & 0 & 90,543 & 268,297 & 217,419 \\
\hline
\end{tabular}

Notes: Analysis assumes free allocation of allowances and includes only power and industry sectors covered by C\&T.

${ }^{\mathrm{a}}$ Allowance price: $\$ 68.24 / \mathrm{t} \mathrm{CO}_{2} \mathrm{e}$; average mitigation cost with trading: $\$ 54.63 / \mathrm{t} \mathrm{CO}_{2}$ e. ${ }^{\mathrm{b}} \mathrm{Negative}$ entries signify revenues from allowance sales.

Source: The authors. 
Appendix Table 2 Simulation of emissions allowance trading in 2030, with auctioning to address equity issues (in million 2015\$ unless otherwise indicated)

\begin{tabular}{|c|c|c|c|c|c|c|c|}
\hline \multirow[t]{2}{*}{$\begin{array}{l}\text { Trading } \\
\text { party }\end{array}$} & $\begin{array}{c}\text { NDC } \\
\text { emissions } \\
\left(\mathrm{mtCO}_{2}\right)\end{array}$ & $\begin{array}{l}\text { Free- } \\
\text { allocation } \\
\text { allowances } \\
\left(\mathrm{mtCO}_{2}\right)\end{array}$ & $\begin{array}{l}\text { Emission } \\
\text { reduction } \\
\text { undertaken } \\
\text { after trading } \\
\left(\mathrm{mtCO}_{2}\right)\end{array}$ & $\begin{array}{c}\text { C\&T } \\
\text { mitigation } \\
\text { cost }\end{array}$ & $\begin{array}{c}\text { Allowances } \\
\text { needed } \\
\text { from } \\
\text { trading or } \\
\text { auction }^{\text {a }}\end{array}$ & $\begin{array}{l}\text { Trading } \\
\text { plus } \\
\text { auction } \\
\text { costs }\end{array}$ & $\begin{array}{l}\text { C\&T } \\
\text { total } \\
\text { cost }\end{array}$ \\
\hline & $\mathbf{I}$ & $(=1 \times 87 \%)$ & 3 & 4 & 5 & 6 & $\begin{array}{c}7 \\
(=4+6)\end{array}$ \\
\hline Australia & 408 & 355 & 0 & 0 & 65 & 5,476 & 5,476 \\
\hline Brazil & 1,197 & $\mathrm{I}, 197$ & II & 916 & 139 & 11,666 & 12,582 \\
\hline Canada & 525 & 457 & 0 & 0 & 206 & 17,237 & 17,237 \\
\hline China & 19,252 & 19,252 & 2,643 & 170,355 & $-2,40 \mathrm{I}$ & $-201,159$ & $-30,804$ \\
\hline EU28 & $3,|4|$ & 2,733 & 74 & 5,839 & 1,133 & 94,940 & 100,780 \\
\hline India & 5,695 & 5,695 & 849 & 49,877 & -849 & $-71,136$ & $-21,259$ \\
\hline Japan & 732 & 637 & 92 & 5,901 & 95 & 7,962 & 13,863 \\
\hline $\begin{array}{l}\text { Mexico and } \\
\text { South America }\end{array}$ & 2,592 & 2,592 & 145 & 9,072 & 185 & 15,495 & 24,567 \\
\hline $\begin{array}{l}\text { North Africa } \\
\text { and Middle East }\end{array}$ & 2,491 & 2,491 & 0 & 0 & 64 & 5,383 & 5,383 \\
\hline Rest of Europe & 109 & 109 & 0 & 0 & 12 & 983 & 983 \\
\hline Rest of the world & 6,570 & 6,570 & 0 & 0 & 716 & 59,948 & 59,948 \\
\hline Russia & $\mathrm{I}, 865$ & 1,865 & 132 & 9,617 & -132 & $-11,089$ & $-1,472$ \\
\hline $\begin{array}{l}\text { Singapore and } \\
\text { South Korea }\end{array}$ & 569 & 569 & 0 & 0 & 250 & 20,942 & 20,942 \\
\hline $\begin{array}{c}\text { Ukraine, Belarus, } \\
\text { and Moldova }\end{array}$ & 532 & 532 & 0 & 0 & 0 & 0 & 0 \\
\hline United States & 4,543 & 3,952 & 0 & 0 & $\mathrm{I}, 733$ & $|45| 8 \mid$, & $|45,18|$ \\
\hline Total & 50,221 & 49,006 & 3,946 & 251,578 & $4,598^{c}$ & $101,828^{d}$ & 353,406 \\
\hline
\end{tabular}

${ }^{a}$ Negative entries signify excess allowances regions can sell in the trading market. ${ }^{b}$ Auction of 13 percent of allowances pertains only to the United States, EU28, Japan, Canada, and Australia; 100 percent free allocation of allowances for all other regions. ${ }^{\mathrm{C}}$ The column total is the sum of all the positive numbers in this column, which represents the total amount of allowances needed from trading and/or auction. 'Since allowances purchased equal allowances sold, this value represents total auction revenues.

\section{References}

Aldy, J. E., W. A. Pizer, and K. Akimoto. 2017. Comparing emissions mitigation efforts across countries. Climate Policy 17(4):501-15.

Bodansky, D. M., S. A. Hoedl, G. E. Metcalf, and R. N. Stavins. 2016. Facilitating linkage of climate policies through the Paris outcome. Climate Policy 16(8):956-72.

Böhringer, C. 2000. Cooling down hot air: a global CGE analysis of post-Kyoto carbon abatement strategies. Energy Policy 28(11):779-89.

Burtraw, D., K. L. Palmer, C. Munnings, P. Weber, and M. Woerman. 2013. Linking by degrees:
Incremental alignment of cap-and-trade markets. Working Paper DP 13-04. Washington, DC:

Resources for the Future.

(CERP) Climate Equity Reference Project. 2016. The Climate Equity Reference Calculator. Stockholm Environment Institute. http://calculator.climateequi tyreference.org/ (accessed October 10, 2016).

Cramton, P., A. Ockenfels, and J. Tirole. 2017. Translating the collective climate goal into a common climate commitment. Review of Environmental Economics and Policy 11(1):165-71. 
Doda, B., and L. Taschini. 2017. Carbon dating: When is it beneficial to link ETSs? Journal of the Association of Environmental and Resource Economists 4(3):701-30.

Flachsland, C., R. Marschinski, and O. Edenhofer. 2009. To link or not to link: benefits and disadvantages of linking cap-and-trade systems. Climate Policy 9(4):358-72.

Fujimori, S., I. Kubota, H. Dai, K. Takahashi, T. Hasegawa, J. Y. Liu, Y. Hijioka, T. Masui, and M. Takimi. 2016. Will international emissions trading help achieve the objectives of the Paris Agreement? Environmental Research Letters 11(10):e104001.

Green, J. F., T. Sterner, and G. Wagner. 2014. A balance of bottom-up and top-down in linking climate policies. Nature Climate Change 4(12):1064-67.

Kitous, A., K. Keramidas, T. Vandyck, and B. Saveyn. 2016. Global energy and climate outlook (GECO 2016): road from Paris. JRC Working Paper 101899. Seville, Spain: Joint Research Centre.

Kverndokk, S., and A. Rose. 2008. Equity and justice in global warming policy. International Review of Environmental and Resource Economics 2(2):135-76.

Metcalf, G. E., and D. Weisbach. 2012. Linking policies when tastes differ: global climate policy in a heterogeneous world. Review of Environmental Economics and Policy 6(1):110-29.

Nordhaus, W. D. 2015. Climate clubs: overcoming free-riding in international climate policy. American Economic Review 105(4):1339-70.

Nordhaus, W. D., and J. G. Boyer. 1999. Requiem for Kyoto: an economic analysis of the Kyoto Protocol. Energy Journal 20(2):93-30.

Ranson, M., and R. N. Stavins. 2016. Linkage of greenhouse gas emissions trading systems: learning from experience. Climate Policy 16(3):284-300.
Rose, A., B. Stevens, J. Edmonds, and M. Wise. 1998. International equity and differentiation in global warming policy. Environmental and Resource Economics 12(1):25-51.

Rose, A., D. Wei, N. Miller, and C. Flachsland. 2017a. The G20 countries should lead the way in designing and participating in a greenhouse gas emissions allowance trading system that will provide adequate financing to enable low-income countries to meet their COP21 pledges. G20 Insights. http://www.g20-insights.org/policy_ briefs/g20-countries-lead-way-designing-partici pating-greenhouse-gas-emissions-allowance-trad ing-system-will-provide-adequate-financing-en able-low-income-countries-meet/ (accessed May 29, 2017).

Rose, A., D. Wei, N. Miller, and T. Vandyck. 2017b. Equity, emissions allowance trading and the Paris Agreement on Climate Change. Economics of Disasters and Climate Change 1(3):203-32.

Stavins, R. N., and R. Stowe, eds. 2017. Market Mechanisms and the Paris Agreement. Cambridge, MA: Harvard Project on Climate Agreements.

UNFCCC. 2015. Paris Agreement, as contained in the report of the Conference of the Parties on its twenty-first session, FCCC/CP/2015/10/Add.1. http://unfccc.int/paris_agreement/items/9485.php (accessed February 10, 2016).

Vandyck, T., K. Keramidas, B. Saveyn, A. Kitous, and Z. Vrontisi. 2016. A global stocktake of the Paris pledges: implications for energy systems and economy. Global Environmental Change 41:46-63. (WRI) World Resources Institute. 2016. CAIT Emission Projections. Washington, DC: World Resources Institute. https://www.wri.org/resour ces/data-sets/cait-emissions-projections (accessed October 10, 2016). 


\begin{abstract}
The coordination of international climate policy, such as linking systems of tradable greenhouse gas (GHG) emissions allowances, can greatly lower the cost to all participants of slowing climate change. We consider alternative policy designs of international agreements that would help implement the 2015 Paris Climate Agreement's GHG reduction pledges. In particular, we examine a stepwise approach to implementing a global system of GHG emissions trading, which includes estimating the benefits of alternative configurations of participating countries. We also illustrate the importance of allowance trading design features, such as the transfer of auction revenues to low-income countries. Numerical simulations indicate that an emissions trading system covering the power and industry sectors in all countries that made unconditional pledges could reduce the associated mitigation costs by more than 72 percent. Moreover, transferring the revenues from the sale of emission allowances could greatly enhance the capability of lower-income countries to meet their Paris Agreement pledges. (JEL: Q54, Q56, Q58, H23, F53)
\end{abstract}

